\title{
THE ROLE OF TECHNOLOGICAL CHANGE IN INCOME INEQUALITY IN THE UNITED STATES ${ }^{1}$
}

\author{
Elena Deskoska, Jana Vlčková*
}

\begin{abstract}
This paper examines the impact of the technological change on income inequality in the United States of America. This is done by integrating theoretical and analytical findings of the channels through which technological change affects income inequality. The research is based on centurylong income inequality data sets, although it prioritises the study of income inequality between the 1970 s and the 2010s. The two major causes of rising income inequality have been technological change and globalisation. The paper also accounts for the other inequality triggers that have resulted from the political and economic structure of the country. The spread of automatisation and computerisation and of other changes associated with The Fourth Industrial Revolution are likely to reinforce skill-biased technological change. Therefore, new measures addressing income inequality, such as Universal Basic Income, are discussed.
\end{abstract}

Keywords: income inequality, technological change, fourth industrial revolution, USA, globalisation JEL Classification: O3, O40, O51, F6, J40

\section{Introduction}

Since the Great Recession of 2008, public discourse on capitalism has shifted. In the USA, it had its incarnation in the rise of the Occupy Wall Street Movement. A contribution of this organised effort, which gained major global support, is the framing of the $99 \%$ and the $1 \%$ phrase that has raised awareness about the crisis of income inequality.

Simultaneously, the world is facing the rapid development and spread of new technologies that many scholars refer to as the Fourth Industrial Revolution (Brynjolfsson and McAfee, 2014). This new age of inventions and artificial intelligence could give our civilisation the potential to flourish although if not managed wisely, many could also be left behind.

In order to increase awareness of the current and future economic policy challenges in terms of rapid-paced technological advancement, the aim of this paper is to examine the main drivers behind income inequality in the USA since the 1970 s, with particular emphasis placed on technological change. Furthermore, it attempts to depict the distributional

1 The authors acknowledge support from the Internal Grant IG210016 "The impact of growing global middle class on selected developing and developed regions".

* University of Economics, Prague, Faculty of International Relations (jana.vlckova@vse.cz). 
implications of technological progress across different income groups in the USA. Finally, it strives to outline a corresponding policy of redistribution.

This research is built on interdisciplinary study ranging from the areas of international trade, economic theory, statistics, and economic history to writings by authors dealing with robotics and technology, technological think tanks, research institutes, and policy papers. The paper provides both theoretical and analytical support for the ways in which technological change and international trade (offshoring) mould the level of wages and employment in the USA.

A deeper insight is attained by decomposing the wages of workers according to the income percentile to which they belong. The study then expands on the primary triggers and is complemented by the secondary causes of income inequality that have either a political or economic background. Drawing on US income inequality trends, the policy implications are listed and include a discussion on universal basic income as a possible re-distributional tool for the country.

\section{Literature Review}

During the 19th century, technology was used as a referral to the mechanical arts. In academia, technology is usually introduced by using the neoclassical model, which views it as a function describing the transformation of inputs (capital and labour) into outputs (Korres, 2008). Technological change thus enables the production of either a greater number of outputs or a higher quality output using the same amount of inputs. A labour intensive technological change can cause an increase in the relative productivity of a certain type of labour that creates a demand gap between skilled and unskilled workers (Violante, 2008). Technological progress can unevenly affect the marginal productivity of capital and labour. Krugman (2012) describes the capital-biased technological change as a kind of change that makes society richer, but workers poorer. As technological change increases the productivity of the machines, it consequently triggers a fall in wages relative to the cost of capital, which could later cause wages to diminish and even redundancies.

Many studies argue that there is a correlation between productivity and technological change (i.e. Abramovitz, 1956). However, productivity growth is not always a result of technological progress. Growth can also be triggered by economies of scale, changes in efficiency, cyclical effects etc. (Rymes, 1971). In other cases, technological change is accelerating but is not necessarily translating into productivity growth (OECD, 2001). The reason for this does not lie in the lack of technological innovation but rather in our limited capabilities to implement it into usable forms (Korres, 2008). This is because technological change is mainly a social process (Rosenberg, 1982).

The three dominant economic theories that address economic growth hold diverse views on the role of technology in this process. Solow's model (Solow, 1956) views technology as an exogenous force that is independent of the traditional factors of production (also called Solow's residual). Its contribution to economic growth can be observed once the economy reaches a steady level and has exhausted the productivity of its capital and labour. The theory of endogenous growth was developed as a response to Solow's model and emphasises the importance of the knowledge that enhances capital and labour (human capital) productivity, therefore generating overall economic growth (Romer, 1994; Barro and Sala-i-Martin, 1992). According to Schumpeter's theory of creative 
destruction, innovation, savings, and imitation are behind the creation of business cycles. Companies that are innovation leaders gain a short-term monopoly on the market and steer competition towards the rest of the businesses that are left with the choice of either following the innovation trends or leaving the market altogether.

Inequality deals with the total distribution of income among individuals and households, whereas poverty is narrowed down only to distribution below the poverty line. However, inequality is independent of the means of distribution, as is the case with the wider notion of welfare, and it is only concerned with the dispersion of distribution (Litchfield, 1999). There are three most commonly used measurements of inequality, which are applied throughout the text: the Gini coefficient, the decile dispersion ratio, and the share of income of the poorest/richest \%. Larger income inequalities manifest themselves through growing unemployment and diminishing wages, hence generally greater social insecurity. According to Standing (2001), the prevailing trend for the past decades is that for many groups there has been a shift from non-wage and non-monetary forms of income to monetary wages. In addition to the diminishing state benefits and wage reliance in the USA, any potential increase in unemployment could significantly impact the level of income inequality. Throughout the text, mostly data on wages and income is used to map the income inequality supported by other data such as productivity and taxes.

The impact of international trade on prices, and consequently wages, was initially explained by Samuelson's factor price equalisation theory (Samuelson, 1948). In his observation, the converging tendencies in the prices of the factors of production in different countries are the result of free trade. Although this theory is criticised for its simplified assumptions by Krugman and Obstfeld (2011), there is evidence that since the liberalisation of trade between developing and developed countries and increasing offshoring, the median wage in the advanced countries including the USA has been stagnating or increasing. In this way, trade has contributed to the growth of income inequality (Ebenstein et al., 2014; Kemeny and Rigby, 2012). Furthermore, since states (and employees) have to compete with many distant emerging countries, this has led to common loose policies of flexibility that have disadvantaged the compensation, job security, social protection, and the bargaining power of the global worker (Standing, 2001).

However, Krugman and Obstfeld (2011) point out that the main reason for the growing gap between low and highly skilled people in the USA is the technology. Many other authors believe that skill-biased technological change is the main driver of inequality (e.g. Feenstra, 2009). That technological change causes short-term job losses is a widely accepted idea in economic theory (Mabry and Sharplin, 1986) although there are conflicting views about the implications of the technological innovation on long-term unemployment. According to Keynes (1963), technological unemployment occurs due to rapid automation and the incapacity of the economic system to quickly create new workplaces that would effectively match the current structure of the labour economy. Brynjolfsson and McAfee (2014) oppose this view and claim that technological unemployment will have only a temporary character and will lead to better and more sophisticated job placements.

The isolated influence of technological change on income inequality depends on the nature of the technological change. If it is dealt with by capital-intensive technological change then the labour input is substituted by the more productive input capital, which raises the returns of the capital owners and knocks down the share going towards labour (Krugman, 2012). On the other hand, the skill-biased technological shift 
causes gaps between the highly-skilled and the less-skilled labour, whereas the demand and the compensation for the latter go down. Both of these types of technological change have contributed to the high level of income inequality in the USA. Finally, the fast-paced digitisation and information, which is the main driver of the so-called Industry 4.0 enabled the existence of superstar enterprises ${ }^{2}$ that can thrive as paramount in a certain sector, gaining monopoly power, and creating a divide between them and the others in that sector. Brynjolfsson and McAfee (2014) also call this luck-biased technological change.

\section{Figure 1 | Inequality triggers in a nutshell}

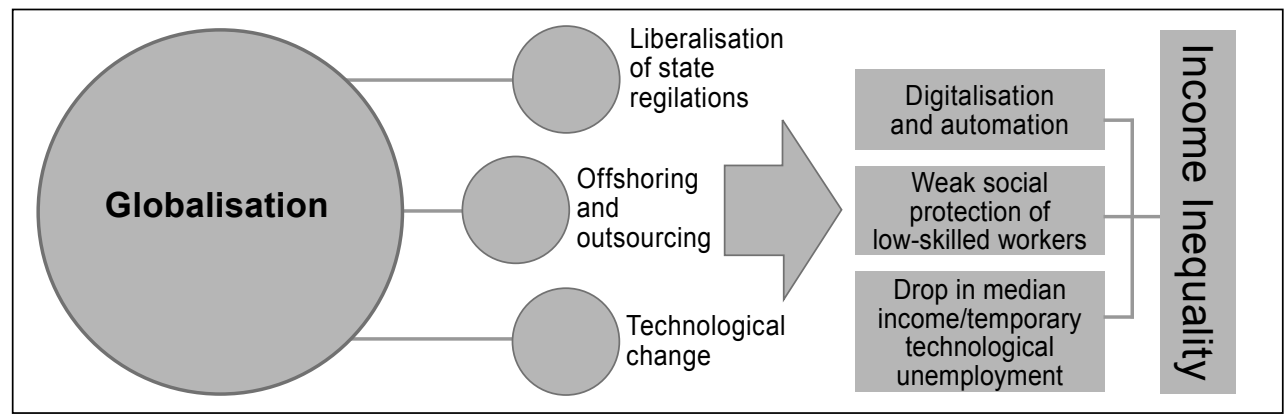

Source: Author's own creation

\section{Analysis: Income Inequality in the United States}

The analysis of US income inequality is based on decomposing income inequality in the following three components: inequality within labour income (wages, salaries, and benefits); inequality within capital income (capital gains, dividends, and interest); and the division of aggregate income between labour and capital.

Kuznets (1955) argued that income inequality typically follows an inverse U-shaped development where it starts rising with the technological change and industrialisation and thereafter is eventually reduced as the majority of workers become employed in the high productivity sectors. The evidence of growing income inequality in the USA has featured since the 1970's without any signs of a downward trend. Whereas in 1915, the top $10 \%$ of the American population held about $40 \%$ of all the income, this number has risen up to $50 \%$ one century later (see Figure 2). In between these years, there has been a period of much lower income inequality across all five groups. The slumps in income in the first half of the century occurred due to the severe economic shocks that followed World War I and the Great Depression. Many businesses were destroyed, leaving their owners deprived of high incomes (Atkinson, Piketty and Saez, 2011). The years after World War II were accompanied by a continuous drop in the curves. American inequality reached its low in the 1960s. In the three decades beginning with the 1980s, the share of US national income in the hands of the richest $10 \%$ has increased by 15 percentage points.

2 Superstars - an expression describing businesses that achieve a monopoly-like power on the market. Helped by the globalisation and digitization, these industries become more important, causing an increase in income inequality because pay at the top pulls away from pay in the middle (Brynjolfsson and McAfee, 2014). 


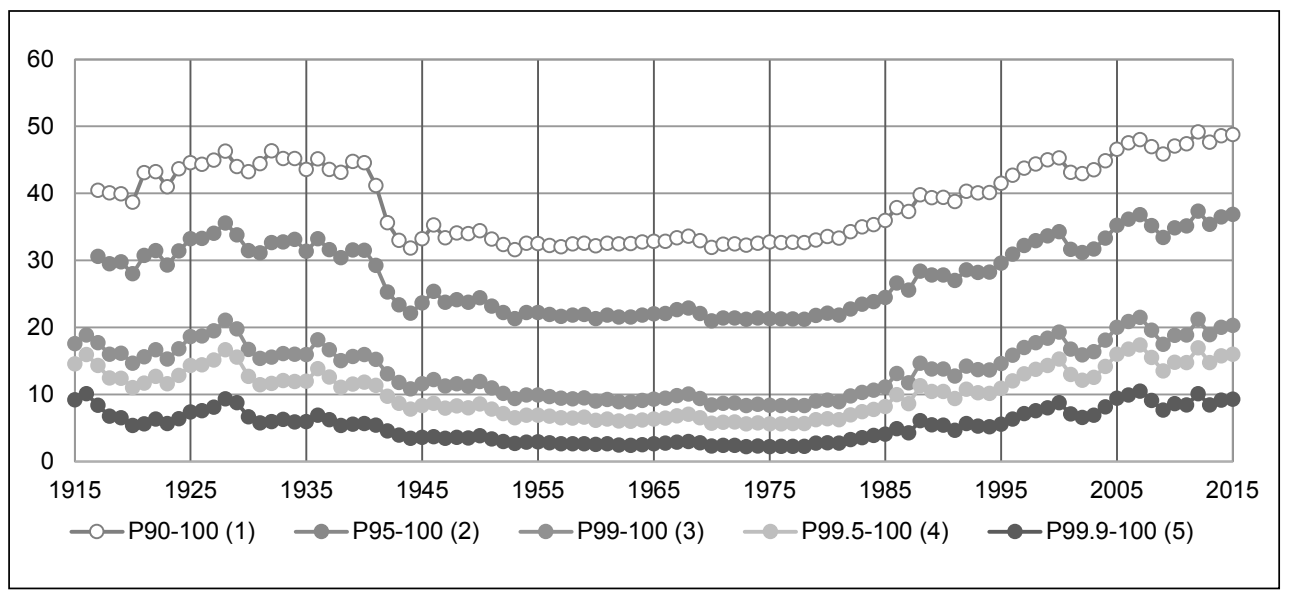

Source of data: (Saez, 2016)

Following the respective curves for each of these three groups, it evident that in recent years, the top $1 \%$ of earners significantly stand out from the others that earn less. This group reached its record share of the US national income shortly before the Great Depression in 1928 , holding up to $20 \%$ of it. Afterwards, particularly during the 1950 s and 1960s their share had dropped to approximately $10 \%$. In 2015, this share rose to $20 \%$. Compared to the other groups, this one has grown the most since the mid 1980s, providing evidence that under conditions of a certain economic structure and technological advancement, the biggest share of income is accumulated by the richest of the rich (the top $1 \%$ ), thereby contributing the most to US income inequality. According to the Economic Report of the President (Council of Economic Advisers, 2016), the overall increase in the share of income going to the top 1\% from 1970 to 2010 is a result of three factors: $68 \%$ is due to increased inequality within labour income; $32 \%$ is due to increased inequality within capital income; and $0 \%$ due to a shift in income from labour to capital. This finding puts the emphasis on labour income inequality although it shows us that capital income is also an important driver of income inequality. Altogether, the groups from the top decile had in the decade between the 1970s and 1980s an increase in income larger than the average economic growth of the American economy at that time (Piketty, 2014).

Despite the fact that both curves in Figure 3 follow the same trend, the biggest differences between them can be observed in the good years of the financial markets (slightly before the market bubbles). Piketty (2014) explains the divergence of the curves as a consequence of the capital gains that reach the maximum immediately before the economic slumps. This is particularly observable in 1928, before the Great Depression, which was the first captured record of maximum capital gains ( $3 \%$ of the national income). The same pattern can be observed in 2000 before the dotcom (internet) bubble and again in 2007 before the Great Recession. Capital gains alone have also contributed to income inequality, having a similar development as the rest of the income that is not the result of a return on capital. These have grown from $34 \%$ in the 1970 s to $46 \%$ in 2010 (see Figure 3). During recessions, income inequality tends to decrease because 
the fall in capital gains is higher than the fall in other types of income. According to Piketty (2014), the inequality upturn contributed to the financial turmoil in the USA in 2008. As the share of income for the richest layers had been increasing, the purchasing power of the American middle and low class had moved downwards, leading to a growing tendency of indebtedness that came as a result of the affordable loans offered in the years before the crisis that these humble households had been unable to repay.

Figure 3 | Income shares of the top $10 \%$ (comparison of the income with/without capital gains)

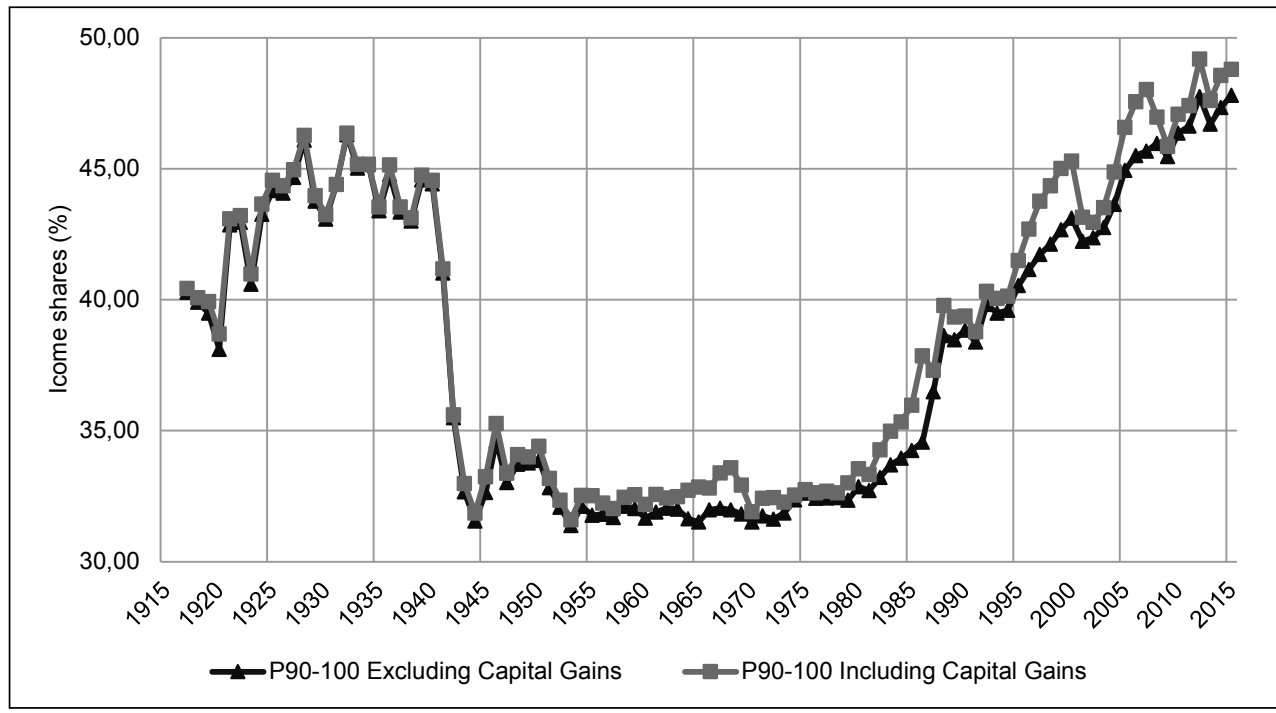

Source of data: (Saez, 2016)

\subsection{Primary Causes of Growth of Income Inequality in the USA. Wage and Productivity Analysis}

The importance of wage analysis stems from the fact that wages are a major determinant of changes in inequality, given that they represent about $80 \%$ of household income in the United States. The data from the US Bureau of Labour Statistics (2015) suggests a real (inflation adjusted) wage growth line that follows a similar trend as the in the top incomes in Figures 2 to 4 . Over a 35-year span, the real earnings for the highest $10 \%$ of earners rose from $\$ 1,422$ per week in 1979 to $\$ 1,898$ per week in 2014 (an increase of $33 \%$ ). For the median worker ${ }^{3}$, things remained almost unchanged with $\$ 733$ per week in 1979 and $\$ 791$ by 2014 (an 8\% increase). Between these years, the lowest earning decile has seen very little or no growth in real weekly wages - from less than $\$ 383$ in 1979 to less than $\$ 379$ in 2014 (see Figure 4). The overall difference between the higher and the lower earners has grown since 1979. In 1979, the ratio of the 90th percentile compared to the ratio of the 10th percentile was 3.7; as of 2014 this ratio had risen to 5.

3 The median weekly earnings are calculated for the full-time wage and salary workers of age 16 and older. The salary numbers $\$ 733$ and $\$ 791$ mean that half of these workers earned at least $\$ 733$ or $\$ 791$ per week and half earned less than that amount. 


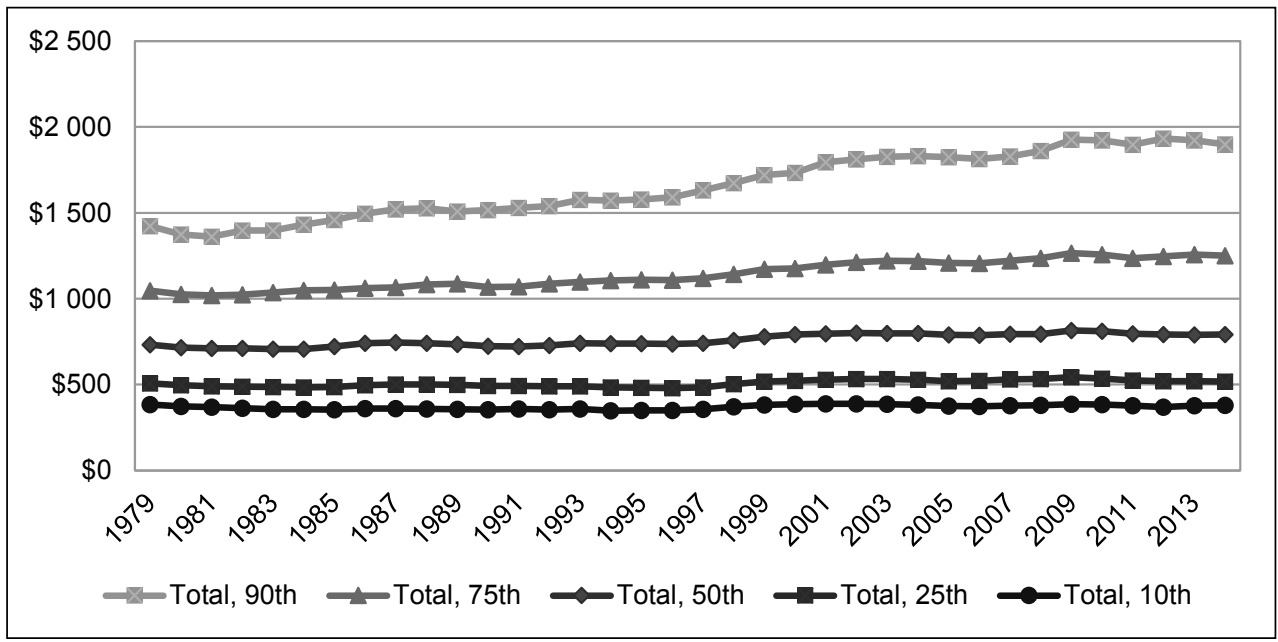

Source of data: (United States Department of Labor, 2015)

As in the case of the previously analysed incomes, the share of the top wages (without capital gains) recorded an increase in the years around the Great Depression and the Great Recession (approaching 46\% of the total income in both cases). Historically, these shares had been influenced by state policies (e.g. progressive taxation and redistribution) that have mitigated wage inequality, especially in the years of World War II up until the mid-1970s. From the 1970 s to 2010 , the share of the top decile in the total wage bill increased by 10 percentage points (from $25 \%$ to $35 \%$ ). The wages of the top $10 \%$, particularly the top $1 \%$ group have grown structurally faster than the average wage. Furthermore, these disparities were not compensated by wage mobility within an individual career (Piketty, 2014).

Regarding the sources of income of the richest in the USA, it can be concluded that the ratios of the income of capital versus the income from labour are getting larger, as an individual moves up the income hierarchy (see Figure 5). As the data for the top 1\% shows, the capital income (dividends, interest, and rents) together with the profit from entrepreneurship (not subject to corporate taxes) make up about half of their earnings. This share is even higher for the top $0.01 \%$, since it reaches up to $70 \%$ with a much lower labour contribution of $30 \%$. This implies that the richer an individual is, the larger the share of their income is composed of capital as opposed to the poorer individual where the main generator of income is labour (wages).

The US median income was increasing steady from the 1950s up until the mid1970s in tandem with productivity, real GDP, and employment (see Figure 6). A period of divergence of the median family income started after 1975, with it moving upwards only slightly, while productivity and GDP per capita growth registered a sharp upsurge. The overall trend shows that from the late 1970s until 2010 the income of the median household has increased only moderately and peaked in 1999 and since then has been stagnating (Brynjolfsson and McAfee, 2014). 
Figure 5 | The composition of the top incomes in the USA in 2015 as a percentage of total income (income shares by sources of income and by fractiles)

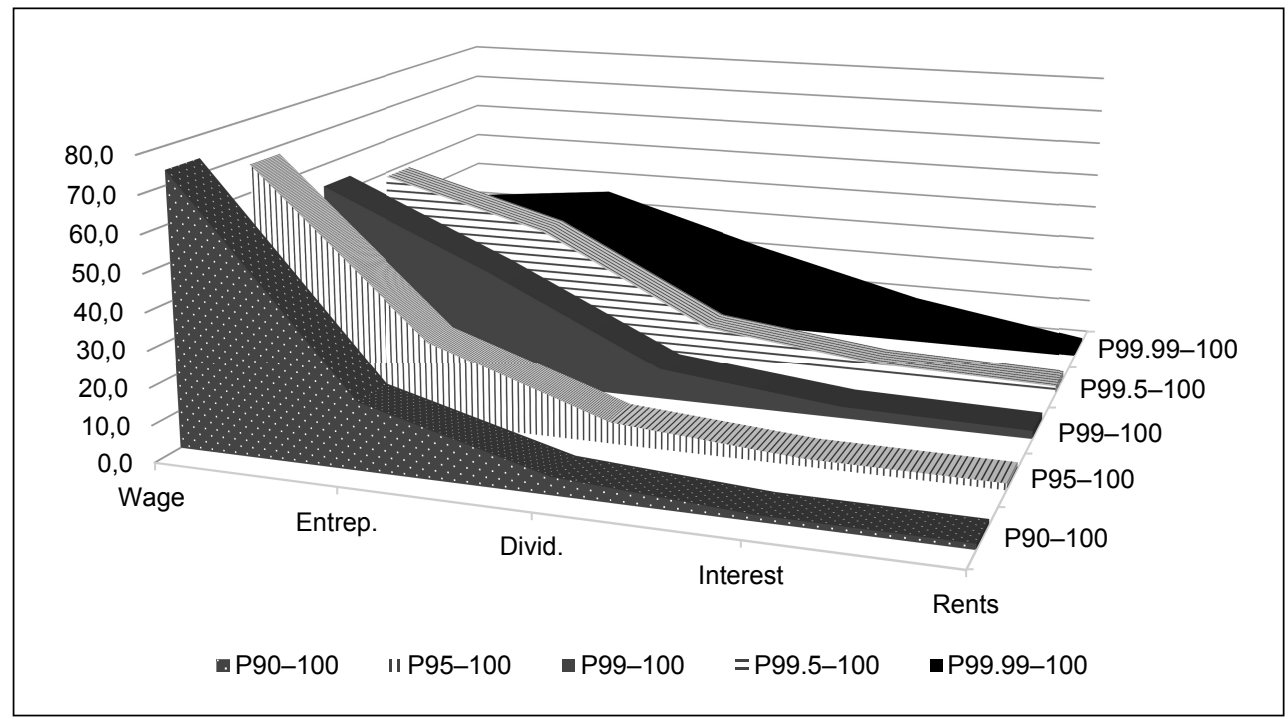

Source of data: (Saez, 2016)

Figure 6 | Trends in labour productivity, real GDP per capita, private employment and median family income in the USA (1950-2010)

\section{When Workers Began Falling Behind}

Until the 1980s labor productivity, real GDP per capita, private employment, and median family income all rose in tandem in the U.S. Then median income started to trail, and around 2000 job growth slowed.

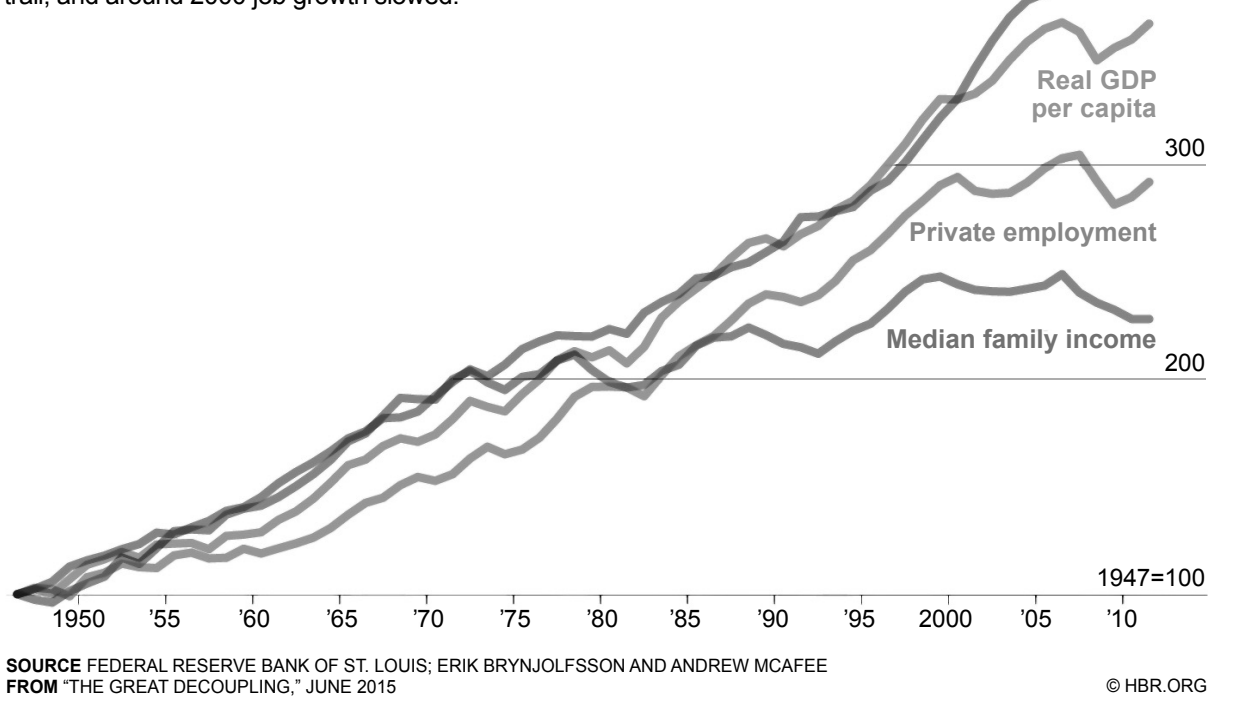

Source: (Brynjolfsson and McAfee, 2014) 
In normal circumstances, changes in average income (total income divided by the total number of people) should not diverge greatly from changes in median income (representing the income of a person in the middle of the distribution). Since 1975, these values have remarkably decoupled and the average income in the USA has seen significant growth while the median has barely changed. Thus, productivity growth only provides the potential for rising income as some groups have received a larger share of it and others have not seen any substantial changes or even experienced a decline in compensation (Mishel and Gee, 2012).

According to the analysis of Mishel and Gee (2012), the biggest contributors to the vast productivity-median income gap for the 2000-2011 period were the growing compensation inequality and the decline in the labour share of income with a respective share of $38.9 \%$ and $45.3 \%$ for the whole gap. During the high productivity period of late $1990 \mathrm{~s}$, the median compensation also accelerated, albeit at a slower pace, creating an annual gap of $1.21 \%$ for the years between 1995 and 2000. This divergence was a consequence of deviating prices and a large soar in compensation inequality, which occurred despite the increasing labour share of income.

Figure 7 | Growth in median hourly compensation and productivity for five subsequent business cycles (1973-2011)

\begin{tabular}{|c|c|c|c|c|c|}
\hline & 1973-1979 & 1979-1995 & $1995-2000$ & $2000-2011$ & 1973-2011 \\
\hline \multicolumn{6}{|l|}{ A. Basic Trends (annual growth) } \\
\hline Median hourly wage & -0.26 & -0.15 & 1.5 & 0.05 & 0.1 \\
\hline Median hourly compensation & 0.56 & -0.17 & 1.13 & 0.35 & 0.27 \\
\hline Average hourly compensation & 0.59 & 0.55 & 2.1 & 0.95 & 0.87 \\
\hline Productivity & 1.08 & 1.29 & 2.33 & 1.88 & 1.56 \\
\hline $\begin{array}{l}\text { Productivity-median } \\
\text { compensation gap }\end{array}$ & 0.52 & 1.46 & 1.21 & 1.53 & 1.3 \\
\hline \multicolumn{6}{|c|}{ B. Explanatory factors (percentage point contribution to gap) } \\
\hline Inequality of compensation & 0.02 & 0.72 & 0.97 & 0.59 & 0.61 \\
\hline Shift in labour share of income & 0.03 & 0.23 & -0.4 & 0.69 & 0.25 \\
\hline $\begin{array}{l}\text { Divergence of consumer } \\
\text { and output prices }\end{array}$ & 0.46 & 0.51 & 0.64 & 0.24 & 0.44 \\
\hline Total & 0.52 & 1.46 & 1.22 & 1.52 & 1.29 \\
\hline \multicolumn{6}{|c|}{ C. Explanatory factors (percent contribution to gap) } \\
\hline Inequality of compensation & $4.80 \%$ & $49.60 \%$ & $80 \%$ & $38.90 \%$ & $46.90 \%$ \\
\hline Shift in labour share of income & $5.50 \%$ & $15.40 \%$ & $-32.50 \%$ & $45.30 \%$ & $19.00 \%$ \\
\hline $\begin{array}{l}\text { Divergence of consumer } \\
\text { and output prices }\end{array}$ & $89.70 \%$ & $35 \%$ & $52.50 \%$ & $15.80 \%$ & $34.00 \%$ \\
\hline Total & $100 \%$ & $100 \%$ & $100 \%$ & $100 \%$ & $100 \%$ \\
\hline
\end{tabular}

Source: (Mishel and Gee, 2012) 
To sum up the entire 1973 to 2011 period, about half (46.9\%) of the growth of the median compensation-productivity gap was a result of the growing inequality of compensation, a third was caused by price differences, and $19 \%$ of the gap occurred due to a decline in labour income share (Mishel and Gee, 2012). Brynjolfsson and McAfee (2014) reached the same conclusion by claiming that most of the growth in productivity translates into comparable growth in average income and the reason behind the anaemic growth of median income is by and large because of increases in compensation inequality.

Technological change affects compensation across different income groups by increasing overall productivity although technology does not affect all inputs with the same intensity (Korres, 2008). Recent technologies, particularly digital, have contributed to enhancing labour productivity by replacing human labour when executing some routine tasks and creating a demand for workers with particular skills. This increased the wages of workers with high levels of human capital while having little impact on the wages of lessskilled workers (Freeman, 1995; Haskel and Slaughter, 2002). This trend of favouring workers with more human capital ${ }^{4}$ is the outcome of the skill-biased technological change (Autor, Katz and Krueger, 1998).

From the 1960s until 1973, the real wages for all U.S. workers grew regardless of their skills. Between 1979 and 2007, there was a steep growth in the wage earnings of those holding a graduate degree (see Figure 8). Large skill imbalances imply that less-skilled workers are much more prone to be eliminated from the work process due to technological changes related to Industry 4.0. Those with a stronger educational background will be augmented with predictable effects to the compensation structure (see below).

Over the last thirty years, US imports have risen much faster than domestic output. This was associated with the increase in imports from developing countries. It is also related to the increase in trade in intermediates and tasks, which accounted for $59 \%$ of US imports in 2011 (OECDiLibrary, 2016). Whereas non-routine cognitive tasks are considered to be place-bound and routine, codifiable tasks are more tradable (Storper and Venables, 2004). Globalisation (international trade and offshoring) thus aggravates the state of income inequality by having a diminishing impact on the wages of domestic workers and on job losses in certain sectors. According to many studies in the 1990s (e.g. Lawrence and Slaughter, 1993; Leamer, 1996), trade was not the major determinant of increased income inequality in developed countries although this was a skill-biased technological change. However, trade with developing countries can strengthen this type of technological advancement.

According to the most recent data for 2015, it is evident that exports of services still play the main role in U.S. trade. These contribute to productivity growth, which leads to larger compensations (skill-biased ones) as productivity growth rewards highly educated and skilled workers but has almost no impact on the increase of the wages of less-skilled workers. Although cheap imports have outcompeted some of the American producers, for U.S. consumers they translate into increased purchase power and wider consumer choice. According to Fajgelbaum and Khandelwal (2016), due to the distributional effects of trade median income, households are gaining more than $25 \%$ of their purchasing power from U.S. trade, while for the lowest third of the income distribution, about $50 \%$ of their purchase power is a result of U.S. trade.

4 Human capital is seen as an asset that can increase workers' compensation. It can be a mix of various skills acquired through education, training or experience (Brynjolfsson and McAfee, 2014). 


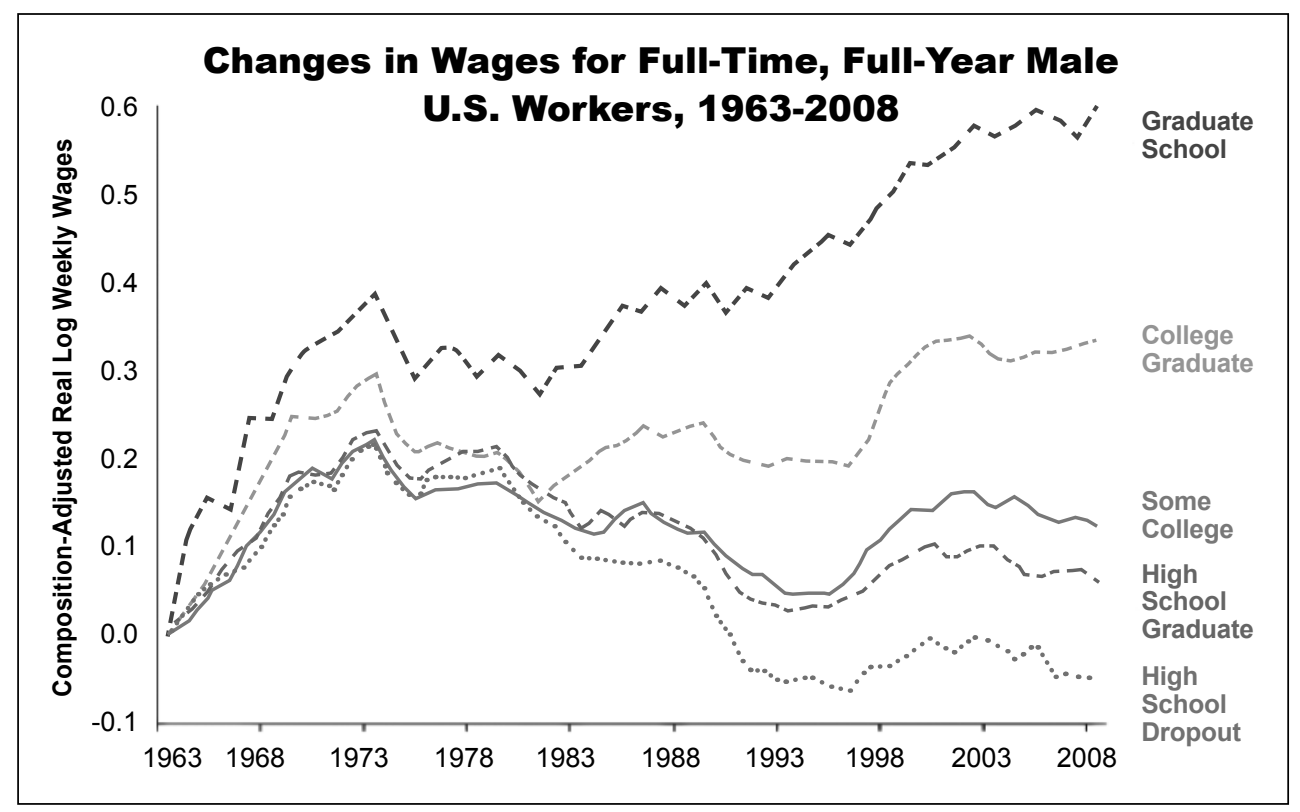

Source: (Acemoglu and Autor, 2011)

Ebenstein et al. (2014) estimate that the U.S. opening up to imports from lowwage countries in the 1980s has contributed to the loss of approximately 6 million jobs and increased income inequality. Workers with advanced degrees have seen the biggest benefit; the only group in manufacturing experiencing a decline in wages are the least educated workers. Kemeny and Rigby (2012) also find that imports from developing countries increase the demand for non-routine activities in the United States and confirm that this affects labour markets in the developed world. On a positive note, the flexibility of the US labour market that enables cross-industrial mobility is beneficial for US workers although switching occupations is not easy (Ebenstein et al., 2014).

\subsection{Secondary Causes of Growth of Income Inequality in the USA}

Derived from the recent literature on income inequality in the U.S. this part integrates the most common additional factors that operate alongside technology and globalisation in aggravating income inequality. These are divided into political (tax and transfer policies, antitrust laws, declining unionisation) and economic forces (rent-seeking behaviour and short-term profit orientation of firms).

\subsubsection{Political Forces of Income Inequality}

According to a number of studies, transfers and federal taxes reduce income inequality. Transfers tend to equalise incomes by boosting income for people at the bottom of the scale, and federal taxes tackle inequality by making income more equal through average tax 
rates. This is achievable because of the progressive taxation system in the USA, where a percentage of the household income is taxed (Congressional Budget Office, 2011).

The analysis in Figure 9 represents the development of the tax rates of the top incomes in four advanced countries. This diagram shows the decline of taxation in the 1980s in the US and suggests that there might be some correlation with Figures 2 to 4 that show the rising top incomes of the richest Americans over the same period. These developments suggest an increase in the proportion of income retained (by the top earners). The growth in the top share of gross income [and the increase in the proportion of income retained by the same group of earners appears to be a result of cuts in top tax rates (Atkinson, 2015). The countries that are becoming more integrated into the global economy have consequently seen their top income shares grow. Similarly, in order to attract workers, countries had to cut tax rates. As Atkinson (2015) puts it "The causal mechanism is, in this case, not from taxes on the top shares, but from globalisation to each of the variables separately" (p. 181).

Figure 9 | Top income tax rates in the US, UK, Germany, and France (1900-2010)

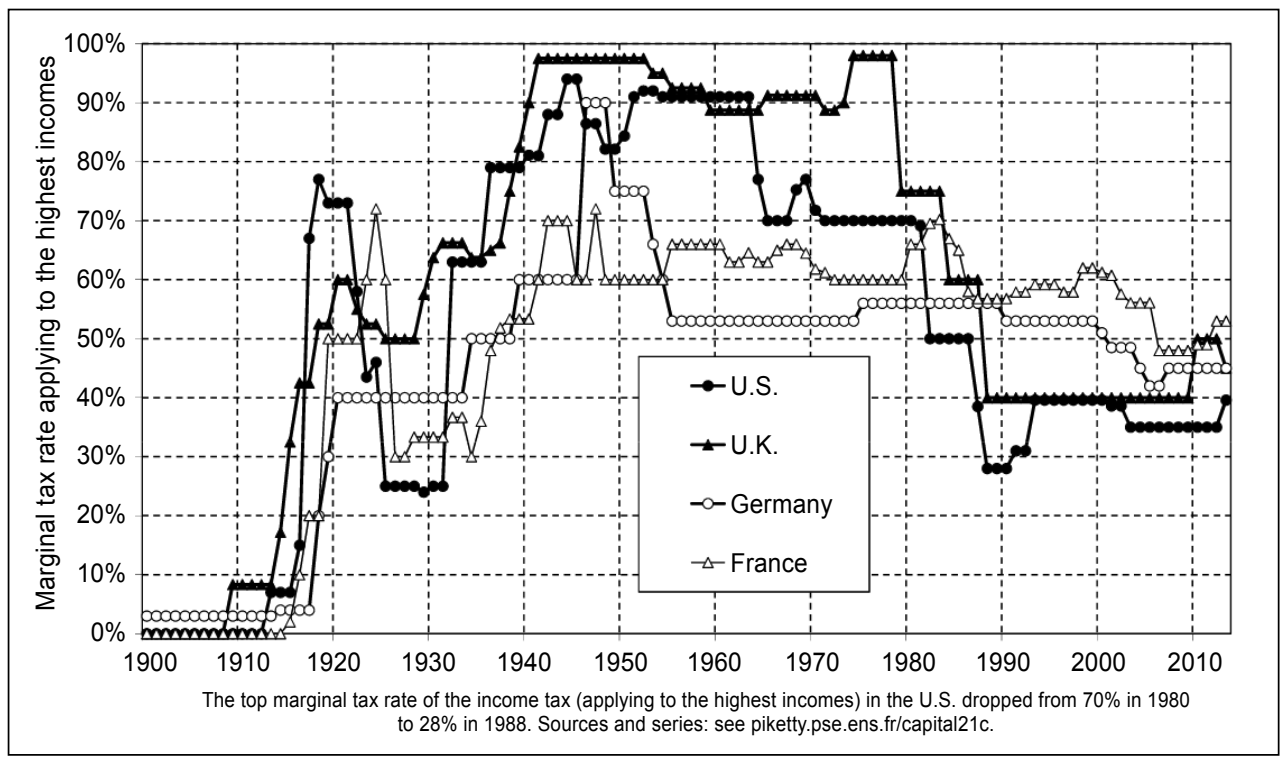

Source: (Piketty, 2014)

Many economists argue that in the period of deteriorating income inequality in the USA (from the 1970s to the present), state policies have made it harder for American labour to mobilise its bargaining power through unions and similar organisational entities. The most important feature of unionisation is the impact that it can have on the development of social policies; thus, the weakening of unionisation in the USA is correlated to the decay of the American middle class as it puts less pressure on policymakers to realise social protection commitments (Hacker and Pierson, 2010; Stiglitz, 2012). The rise of corporate lobbying versus the decline of unions created a setting in which the compensation-related interests of the average American are practically obliterated (Hacker and Pierson, 2010). 
The growing role of digitisation reinforced the creation of winner-take-all markets, enabling digital business owners to minimise costs, as the marginal costs of production and reproduction, to amounts close to zero (Shapiro and Varian, 1999). This process, empowered by digital technologies, created a large divide in the share of profit even between top superstar performers and the second best provider on the specific market (Brynjolfsson and McAfee, 2014). Market power contributes to growing inequality since its tendency to raise the return on capital helps to perpetuate disproportionate income distribution. Technological change facilitates market power by creating loose regulatory conditions in which these types of superstar firms can thrive. This is also possible through intellectual property protection or network effects, which enable firms to achieve market power. The adoption of looser antitrust regulation has contributed to the growing disparities by increasing the market power for more business entities (Baker and Salop, 2015).

\subsubsection{Economic Forces of Income Inequality}

Many economists (i.e. Stiglitz, 2012; Piketty, 2014) have pointed to another factor of growing income inequality - economic rents or also rent-seeking behaviour. Rents are defined as "the unproductive income paid to labour or capital above what is necessary to keep that labour at work or capital invested" (Council of Economic Advisers, 2016, p. 22). These arise when there is imperfect competition in a given market. This market power enables cash sums that are way above their costs and reasonable returns of capital. Stiglitz (2015) refers to this as a practice of generating wealth not by creating any valuable activity, but rather by taking it from others. The prevention of growing inequality that is stemming from rent-seeking behaviour should be addressed through opening the U.S. market up to a wider set of competitors, or by reducing the abuse of market power that creates unproductive inequality (Council of Economic Advisers, 2016). Stiglitz (2015), on the other hand, proposes massive changes to tax laws, regulations, and reshaping of the financial sector (e.g. to increase the tax rate of the top $1 \%$ by $5 \%$ ).

\subsection{Pace of Technological Change and Implications for U.S. Jobs}

Ray Kurzweil (2001), one of the leading futurologists, predicts that in few decades the exponential growth of machine intelligence will surpass human intelligence - and this will lead to the singularity that he explains as a technological change so rapid and profound that it represents a rupture in the fabric of human history. Jorgenson and Wessner (2006) believe that there is a good chance that technological progress will follow the course predicted by Moore's law, ${ }^{5}$ unless there are some impediments that cannot be easily overcome. On the other hand, some chipmaker companies have admitted that their rate of progress in recent years did not achieve the overly-optimistic predictions set by Moore's law (Economist.com, 2016). Numerous new technologies that might reshape the world in a decade are in limited use or exist only as laboratory prototypes and implementation

5 Moore's law is a computing term which originated around 1970; the simplified version of this law states that processor speeds, or overall processing power for computers, will double every two years. Or more precisely, the number of transistors on an affordable CPU would double every two years (see Mooreslaw.org, 2016). 
of super-intelligent technologies by companies will not keep up with the pace of their development due to restrictive governmental regulations (Gordon, 2014).

The rapid technological advancement and productivity growth in terms of lowering prices are good news for businesses, consumers, and for the global economy as a whole. Alternatively, the automation of jobs could in near future potentially make millions of workers redundant (only in the US). The lowering costs of the means of production make the new human-labour-replacing technologies attractive to businesses. The artificial intelligence of machines could, in the foreseeable future, reach the same level as human intelligence while advanced reasoning requires less computation, thus making all the hard problems easy to solve. Nevertheless, executing low-level tasks (e.g. grasping objects) that require precise motion would be more complicated to achieve because they depend on extensive computational resources (the so-called Moravec paradox; see Moravec, 1998).

Computers are good at routine tasks that require precision and following rules and when executing cognitive tasks they are not exposed to some of the human biases and do not need to fulfil any non-occupational related tasks (sleeping, eating etc.). Computers can thus supplement people in many routine cognitive tasks (e.g. fraud detection, medical diagnostics, analysing data in legal and financial services) (Frey and Osborne, 2013). Furthermore, machine learning enables computers to build learning models based on data inputs (e.g. a particular movement in robots) without strictly following program instructions (Bishop, 2006). The current weaknesses of artificial intelligence (hereinafter AI) consist of the inability to perform the type of tasks that humans or animals do subconsciously (e.g. analysing visual scenes, having common sense). Once there is a way to solve these fallbacks, humanity will be one step away from creating human-level intelligent machines.

Overall, as indicated by Fray and Osbourne (2011) in Figure 9, around 47\% of US jobs are susceptible to automation within the next decade or two and belong in the highrisk-of-automation category (particularly in production, logistics and transportation or administration). Thus, people should focus on the activities in which they have a competitive advantage over computers although such activities are nowadays becoming scarce. In the past, due to technological change, workers from one sector were moving to another, more progressive one. Nowadays, all three typical sectors (agriculture, manufacturing, and service) are subject to technological unemployment, thereby making millions of workers redundant as there are no other sectors to absorb those workers whose skills have become obsolete (Levy and Murnane, 2014). Since both wages and educational attainment are negatively correlated to the probability of computerisation, this will lead to labour market polarisation. The only sector relatively less endangered by automation and computerisation is the knowledge sector (the probability is the lowest, estimated at $33 \%$ ), which includes jobs in science, computer programming, education, consultancy, technology, elite entrepreneurship etc. (Levy and Murnane, 2014). Thus, technological change will reduce the demand for low-skilled and low-wage jobs although this has already been happening (see above).

\section{Policy Implications}

The entire data presented in the chapters above suggests that the trend (starting from the late 1970s) of the widening income gap between populations with different education levels is likely to continue. The wages of the population in the most developed countries 
(including the USA) in today's circumstances of strong global competition and growing job automation are unlikely to grow. Negotiating higher wages, hindering international trade, withdrawing offshore jobs or limiting migration would be counterproductive not only in the American context but also for the entire global economy. Instead, unions, lobbyists, and the rest of civil society need to assume new positions regarding the growing income disparities. This includes exploring policies that would secure against the possible outcome of the Fourth Industrial Revolution - complete redundancy of nearly half of the US working-age population.

The recent shift in US political leadership suggests future budget cuts to programmes that have been constructed to support people with low and moderate means (Kogan and Friedman, 2014). The new American administration appears to be making efforts that would further aggravate the current level of income inequality. Increasing trade barriers and limiting FDI would be counterproductive as these measures ignore the complex nature of the global economy and the benefits that offshoring has brought to the United States. Neo-Marxist economists argue that income inequality in the US should be eliminated by a substantial rise in the marginal tax rates on the highest income earners (Piketty, 2014; Stiglitz, 2015). The prevalent concerns that large-scale immigration of unskilled workers is harming the prospects of native-born Americans should be viewed with reserve. Despite the US immigration policies and processes, the whole movement of foreign workers to the US has a beneficial effect on US incomes (Brynjolfsson and McAfee, 2014).

One of the measures that could address the issue of technological unemployment and income inequality is the implementation of Unconditional Basic Income (UBI) in the US. This is defined as a periodic cash payment unconditionally delivered to all citizens on an individual basis, without means test or work requirement [BIEN, 2016]. This programme makes the case for a universal social security tool and has a support-base comprised of academics, thinkers, politicians, and businessmen, some having leftist (e.g. Tobin, Samuelson) and others rightist (Hayek, Friedman) political convictions. The role of UBI in the current setting of intensifying income discrepancies is to create a working system that enables dignified social protection by preserving the free functioning of markets and sustaining technological advancement while ensuring that everyone has a minimum standard of living and is able to act as a consumer. Those willing to improve incomes can do so by working, investing, starting a company, or through other activities (Davala et al., 2015). In terms of income inequality, UBI provides a means to maintain demand and consumption and also provides a security platform for the unemployed during retraining in times of increasing labour market flexibility (Sage and Diamond, 2017).

Criticism is levelled at UBI in two major directions - the first towards its supposed unaffordability and the second that it assumes that it would discourage work (Cass, 2016; Greenstein, 2016). However, there is no clear evidence for these assumptions since some social and behavioural scientists have found that work is one of the principal ways that people obtain other important values: self-worth, community, dignity, engagement, etc. (Davala et al., 2015). According to Hetschko, Knabe, Schoeb (2012), the claims that UBI would discourage individuals from seeking employment are also unsustained, as the status of being unemployed leads to loss of identity and life satisfaction. One of the major challenges is the significant costs of UBI, which would require higher taxes and a larger state. Despite being costly, existing state subsidies are remarkably high and, in most cases, are both regressive and unjustifiable for growth or welfare. Similarly, existing social 
insurance schemes are subject to large bureaucracy (Davala et al., 2015; Gordon, 2014). Thus, UBI could simplify the US social system, cut bureaucracy, information asymmetry, and rent-seeking behaviour. However, large political and social debate is needed along with setting the appropriate level of a minimum guaranteed income.

\section{Conclusion}

The discourse on income inequality can go back and forward between two opposing views; the first containing the negative outlook of the diminishing material, bargaining, and political capacities of the majority of the population contrasted by the strengthening power of the elite (e.g. Piketty and Saez, 2003). In the second interpretation, inequality is seen as a driver for change and progress (e.g. Li and Zou, 1998). Although some levels of income inequality can motivate breakthroughs, the levels recorded in the USA for the last 30 years point to a deep systemic dysfunctionality that actually hampers growth and prosperity.

The two major causes of income inequality are technological change and globalisation, which are mutually interconnected. The overall inequality growth in the USA is by and large a consequence of increased income inequality among labour $(68 \%$ of the total inequality rise is caused by it) and the rest is caused by unequal income shares of capital (32\%) (Council of Economic Advisers, 2016). This pattern of income division is mostly a result of technological advancement. Technological change also causes short-term job losses as it takes some time for the economic system to create new job positions (Mabry and Sharplin, 1986). Nevertheless, the more concerning negative impact of this is that it might create long-term unemployment by diminishing the demand for certain types of labour, whereas this new structure would be unable to absorb the newly-redundant workers that lack the required skills.

Although income inequality in the USA is primarily a consequence of technological change and globalisation, it is further enforced by the change in the political and economic structure in the USA (Piketty, 2014; Atkinson, 2015; Stiglitz, 2012). These secondary factors include weak social protection stemming from the relaxed tax and re-distributional system; the diminishing wage effect of declined unionisation; insufficient implementation of antitrust laws that has created strong corporation with sufficient power to shape state policies and accumulate wealth on the back of consumers; and lastly, rent-seeking behaviours and the favouring of short-term profit goals of U.S. businesses [Stiglitz, 2015]. The impacts of the technological momentum in the USA are particularly observable from the late 1970s and overlap with the offset of globalisation. The century-long data on the top U.S. incomes shows that the richest $1 \%$ of U.S. households gained a record high share of the national income in recent years.

The biggest contributor to U.S. income inequality is the top $1 \%$ income group, which has seen a strong increase in earnings between 1970 and 2010. In contrast, the most deprived are the lowest percentiles (which typically include workers earning their income from a job in the first or the second sector). Also largely affected are the median workers, whose incomes have recorded an anaemic growth. The median wage/productivity decoupling suggests that higher productivity only provides the potential for increasing wages, the degree of which is further remoulded by the state's regulatory setting (Mishel and Gee, 2012). 
The wages in the USA are also dependent on the educational level and skills of the workers. Since the 1970s, the country has been going through a skill-biased technological change that has strongly affected the lowest skilled workers. As technological advancement and productivity growth lower the prices of production, the prospect of more intensive job automation in the USA is becoming a reality. The overall susceptibility of the near future automation of all U.S. jobs is approximately $47 \%$ although jobs that are part of the knowledge sector hold the smallest chance of computerisation in the decades to come and those at the lower end (the low-skilled) are the most threatened by the emerging technologies (Fray and Osborne, 2013). According to some scholars, automation and computerisation would probably represent the next stage of job dislocation but this time jobs that were outsourced due to lower labour costs would return the U.S (Krugman and Sachs, 2015).

One of the policies for addressing income inequality in the US, with regard to the growing automation and digitalisation of the workplace, could be universal basic income. This is a non-discriminatory social security tool that would guarantee the living minimum of each US citizen. It could also address other issues that are related to social insecurities - e.g. encourage the bargaining power of the worker, deter the rise of populism and support for regressive political actions. Finally, it supports international cooperation and enables further technological progress as it suppresses the fears of social uncertainties. However, since this measure has not been widely implemented, the overall potential impact remains unknown.

\section{References}

Abramovitz, M. (1956). Resource and output trends in the United States since 1870. In: Resource and output trends in the United States since 1870. National Bureau of Economic Research, Inc., pp. 1-23.

Acemoglu, D. and Autor, D. (2011). Skills, Tasks and Technologies: Implications for Employment and Earnings. Handbook of Labor Economics, 4(B), pp. 1043-1171, https://doi.org/10.1016/S0169-7218(11)02410-5

Atkinson, B. A. (2015). Inequality: what can be done. Boston: Harvard University Press.

Atkinson, B. A., Piketty, T. and Saez, E. (2011). Top Incomes in the Long Run of History. Journal of Economic Literature, 49(1), pp. 3-71, https://doi.org/10.1257/jel.49.1.3

Autor, D. H., Katz L. F. and Krueger, A. B. (1998). Computing Inequality: Have Computers Changed the Labor Market? The Quarterly Journal of Economics, 113(4), pp. 1169-1213, https://doi.org/10.1162/003355398555874

Baker, J. and Salop, S. (2015). Antitrust, Competition Policy, and Inequality. Georgetown Law Journal Online, 104(1), pp. 1-28.

Barro, R. J. and Sala-i-Martin, X. (1992). Convergence. Journal of Political Economy, 100(2), pp. 223-251.

BIEN (2016). Basic Income Earth Network, [online]. Available at: http://basicincome.org/basic-income/faq/\#definition [Accessed 21 Aug. 2017].

Bishop, C. (2006). Pattern recognition and machine learning. Singapore: Springer.

Brynjolfsson, E. and McAfee, A. (2014). The second machine age. New York: W. W. Norton \& Company. 
Cass, O. (2016). Why a Universal Basic Income is a Terrible Idea. [online] National Review. Available at: https://www.nationalreview.com/2016/06/universal-basic-income-ubi-terrible-idea [Accessed 21 Aug. 2017].

Congressional Budget Office, (2011). Trends in the Distribution of Household Income Between 1979 and 2007, [online]. Available at: http://www.cbo.gov/sites/default/files/cbofiles/ attachments/10-25-HouseholdIncome.pdf [Accessed 21 Aug. 2017].

Davala, S., Jhabvala, R., Standing, G. and Mehta, S. K. (2015). Basic income: a transformative policy for India. London: Bloomsbury Publishing.

Ebenstein, A., Harrison, A., McMillan, M. and Phillips, S. (2014). Estimating the Impact of Trade and Offshoring on American Workers Using the Current Population Surveys. The Review of Economics and Statistics, 96(4), pp. 581-595, https://doi.org/10.1162/REST_a_00400

Council of Economic Advisers, (2016). Annual Report of the Council of Economic Advisers, [online]. Available at: http://www.presidency.ucsb.edu/economic_reports/2016.pdf [Accessed 22 Aug. 2017].

Fajgelbaum, P. D. and Khandelwal, A. K. (2016). Measuring the Unequal Gains from Trade. The Quarterly Journal of Economics, 131(3), pp. 1113-1180, https://doi.org/10.1093/qje/qjw013

Feenstra, R. C. (2009). Offshoring in the global economy. Cambridge, MA: The MIT Press.

Freeman, R. (1995). Are Your Wages Set in Beijing? The Journal of Economic Perspectives, 9(3), pp. 15-32, https://doi.org/10.1257/jep.9.3.15

Frey, C. B. and Osborne, M. A. (2013). The future of employment: how susceptible are jobs to computerisation? Oxford: Oxford University Press.

Gordon, N. (2014). The Conservative Case for a Guaranteed Basic Income. [online] The Atlantic. Available at: https://www.theatlantic.com/politics/archive/2014/08/why-arentreformicons-pushing-a-guaranteed-basic-income/375600 [Accessed 12 Aug. 2017].

Greenstein, R. (2016). Commentary: Universal Basic Income May Sound Attractive but, If It Occurred, Would Likelier Increase Poverty Than Reduce It. [Blog] Huffpost. Available at: https://www.huffingtonpost.com/bob-greenstein/commentary-universalbasi_b_10229506.html [Accessed 12 Aug. 2017].

Hacker, J. and Pierson, P. (2010). Winner-take-all politics: How Washington made the rich richer - and turned its back on the middle class. New York: Simon and Schuster.

Haskel, J. and Slaughter, M. J. (2002). Does the Sector Bias of Skill-biased Technical Change Explain Changing Skill Premia? European Economic Review, 46(10), pp. 1757-1783, https://doi.org/10.1016/S0014-2921(01)00185-4

Hetschko, C., Knabe, A. and Schöb, R. (2012). Identity and Wellbeing: How Retiring Makes the Unemployed Happier. [online] CEPR's Policy Portal. Available at: https://voxeu.org/ article/how-retiring-makes-unemployed-happier [Accessed 21 Aug. 2017].

Jorgenson, D. W. and Wessner, Ch. W., eds., (2006). Software, growth, and the future of the U.S. economy. Washington: The National Academies Press.

Kemeny, T. and Rigby, D. (2012). Trading Away What Kind of Jobs? Globalization, Trade and Tasks in the US Economy. Review of World Economics, 148(1), pp. 1-16, https://doi.org/10.1007/s10290-011-0099-5

Keynes, J. M. (1963). Essays in persuasion. New York: Norton Library.

Kogan, R. and Friedman, J. (2014). Ryan Plan Gets 69 Percent of Its Budget Cuts from Programs for People with Low or Moderate Incomes. [Blog] Huffpost. Available at: 
https://www.huffingtonpost.com/richard-kogan/ryan-budget-gets-69-perce_b_5086544. html [Accessed 12 Aug. 2017].

Korres, G. (2008). Technical change and economic growth: Inside the knowledge based economy. 2nd ed. Aldershot, Hants: Ashgate.

Krugman, P. and Sachs, J. (2015). Globalization, Technological Change, and Inequality: Jeffrey Sachs and Paul Krugman in Conversation. [video] Youtube.com. Available at: https://www.youtube.com/watch?v=K_GtNgUxIJQ [Accessed 21 Aug. 2017].

Krugman, P. and Obstfeld, M. (2011). International economics. 9th ed. London: Pearson Education.

Krugman, P. (2012). Capital-Biased Technological Progress: An Example (Wonkish). [Blog] New York Times Blog. Available at: https://krugman.blogs.nytimes.com/2012/12/26/capital-biasedtechnological-progress-an-example-wonkish [Accessed 23 Aug. 2017].

Kurzweil, R. (2001). The Law of Accelerating Returns. [Blog] Kurzweil Accelerating Intelligence. Available at: http://www.kurzweilai.net/the-law-of-accelerating-returns [Accessed 12 Aug. 2017].

Kuznets, S. (1955). Economic Growth and Income Inequality. The American Economic Review, 45(1), pp. 1-28.

Lawrence, R. Z. and Slaughter, M. J. (1993). International Trade and American Wages in the 1980s: Giant Sucking Sound or Small Hiccup? Brookings Papers on Economic Activity, 24(2), pp. 161-226.

Leamer, E. (1996). In search of Stolper-Samuelson effects on US wages. Cambridge, MA: National Bureau of Economic Research.

Levy, F. and Murnane, R. (2014). The new division of labor: how computers are creating the next job market. New Jersey: Princeton University Press.

$\mathrm{Li}, \mathrm{H}$. and Zou, H. (1998). Income Inequality is not Harmful for Growth: Theory and Evidence. Review of Development Economics, 2(3), pp. 318-334, https://doi.org/10.1111/1467-9361.00045

Litchfield, J. A. (1999). Inequality: Methods and Tools. [online] World Bank. Available at: http://siteresources.worldbank.org/INTPGI/Resources/Inequality/litchfie.pdf [Accessed 13 Dec. 2017].

Mishel, L. and Gee, K.-F. (2012). Why Aren't Workers Benefiting from Labour Productivity Growth in the United States? International Productivity Monitor, Volume 23, pp. 31-43.

Moravec, H. (1998). When Will Computer Hardware Match the Human Brain? Journal of Evolution and Technology, [online]. Volume 1. Available at:

https://www.jetpress.org/volume1/moravec.htm [Accessed 3 Aug. 2017].

Mooreslaw.org, (2016). Moore's Law. [online] Available at: http://www.mooreslaw.org [Accessed 5 Jan. 2017].

OECDiLibrary, (2016). OECD-WTO: Statistics on Trade in Value Added, [online]. Available at: http://www.oecd-ilibrary.org/trade/data/oecd-wto-statistics-on-trade-in-value-added_ data-00648-en [Accessed 3 Jan. 2016].

Piketty, T. (2014). Capital in the twenty-first century. Cambridge, MA: Harvard University Press.

Piketty, T. and Saez, E. (2003/2016). Income Inequality in the United States, 1913-1998. Quarterly Journal of Economics, 118(1), pp. 1-39, https://doi.org/ 10.1162/00335530360535135, (Tables and Figures updated to 2015 in Excel format, June 2016). [online] Available at: https://eml.berkeley.edu/ saez/\#income [Accessed 5 Jan. 2017]. 
Romer, P. M. (1994). The Origins of Endogenous Growth. The Journal of Economic Perspectives, 8(1), pp. 3-22, https://doi.org/10.1257/jep.8.1.3

Rosenberg, N. (1982). Inside the black box: technology and economics. New York: Cambridge University Press.

Rymes, T. K. (1971). On concepts of capital and technical change. Cambridge: Cambridge University Press.

Sage, D. and Diamond, P. (2017). Europe's new social reality - the case against universal basic income. 1st ed. [pdf] Policynetwork.org. Available at:

http://www.policy-network.net/publications/6190/Europes-New-Social-Reality-the-caseagainst-Universal-Basic-Income [Accessed 20 Aug. 2017].

Samuelson, P. A. (1948). International Trade and the Equalisation of Factor Prices. The Economic Journal, 58(230), pp. 163-184, https://doi.org/10.2307/2225933

Shapiro, C. and Varian, H. R. (1999). Information rules: A strategic guide to the network economy. Boston: Harvard Business School Press.

Solow, R. M. (1956). A Contribution to the Theory of Economic Growth. The Quarterly Journal of Economics, 70(1), pp. 65-94, https://doi.org/10.2307/1884513

Standing, G. (2001). Global Insecurity: Restructuring Social Income. [online] Guystanding.com. Available at: https://www.guystanding.com/files/documents/Global_insecurity_-restructuring_social_income_2001.pdf [Accessed 4 Apr. 2017].

Stiglitz, J. (2012). The price of inequality: How today's divided society endangers our future. New York: W. W. Norton \& Company.

Stiglitz, J. (2015). The Origins of Inequality, and the Policies to Contain it. National Tax Journal, 68(2), pp. 425-448, https://doi.org/10.17310/ntj.2015.2.09

Storper, M. and Venables, A. J. (2004). Buzz: Face-to-Face Contact and the Urban Economy. Journal of Economic Geography, 4(4), pp. 351-370, https://doi.org/ 10.1093/jnlecg/lbh027

Economist.com, (2016). After Moore's Law. [online] Available at: https://www.economist.com/technology-quarterly/2016-03-12/after-moores-law [Accessed 13 Apr. 2017].

United States Department of Labor, (2015). A Look at Pay at the Top, the Bottom, and in Between, [online]. Available at: https://www.bls.gov/spotlight/2015/a-look-at-pay-at-the-top-thebottom-and-in-between/home.htm [Accessed 23 Apr. 2017].

Violante, G. (2008). Skill-Biased Technical Change, [online]. Available at: http://www.econ.nyu.edu/user/violante/Books/sbtc_january16.pdf [Accessed 14 Jan. 2017]. 